Article

\title{
The Evolution of China's International Aviation Markets from a Policy Perspective on Air Passenger Flows
}

\author{
Jiaoe Wang ${ }^{1,2}$, Haoran Yang ${ }^{3,4, *}$ and Han Wang ${ }^{5}$ \\ 1 Key Laboratory of Regional Sustainable Development Modeling, Institute of Geographic Sciences and \\ Natural Resources Research, Chinese Academy of Sciences, Beijing 100101, China \\ 2 College of Resources and Environment, University of Chinese Academy of Sciences, Beijing 100049, China \\ 3 School of Urban and Regional Science, East China Normal University, 500 Dongchuan Road, \\ Minhang District, Shanghai 200241, China \\ 4 The Center for Modern Chinese City Studies, East China Normal University, 3663 North Zhongshan Road, \\ Putuo District, Shanghai 200062, China \\ 5 Air Transport Institute, China Academy of Civil Aviation Science and Technology, Beijing 100028, China \\ * Correspondence: hryang@re.ecnu.edu.cn
}

Received: 25 April 2019; Accepted: 24 June 2019; Published: 28 June 2019

check for updates

\begin{abstract}
China's international air transportation has experienced tremendous growth and major reforms over the past two decades. While there has been a considerable discussion on the evolution of China's domestic aviation market, studies on China's international aviation markets have been limited. This paper first describes the historical development of China's international aviation market and then, based on actual origin/destination $(\mathrm{O} / \mathrm{D})$ passenger flow data, explores the relevant evolution of China's international air networks from the perspectives of the spatial distribution of international air networks and clustering characteristics of international air passengers. The development of China's international aviation market can be attributable to the deregulation process in China's aviation market and a broad "opening up" strategy in the global forum after 1990. Due to China's proximity to East Asia and Southeast Asia, China's international air networks show an obvious clustering pattern for short and medium-haul travel in Asia. In addition, average international air travel distance, institutional and policy changes, and increasing foreign trade and foreign tourism are crucial for the expansion of China's international air networks.
\end{abstract}

Keywords: international aviation; passenger flows; air travel; development; evolution; policy regulation

\section{Introduction}

The rapid globalization and regionalization of the world after the 1980s dramatically increased functional interactions between countries, which has had a significant effect in increasing international travel, particularly air travel [1]. As one of the major transport modes for long-distance travel, airlines facilitate functional interaction on an international scale, thereby catalyzing globalization and spurring social and economic development [2]. This phenomenon became even more obvious after the deregulation of the aviation market of the US and Europe, during which greater cooperation was established between domestic airlines and international airlines. A result of this collaboration was that international air travel became a major travel trajectory in Europe, especially in light of the fact that the spatial scales of European countries are relatively small [3].

International experience has shown that the deregulation process presented a complete form, with full freedom of access to markets, capacity, and pricing in developed countries (the US and Europe) [4], 
and an incomplete form in developing countries (India, Brazil, and China) [5,6]. China's aviation market has experienced exponential growth over recent decades since its partial deregulation in the 1980s [7-9]. According to figures from the Official Airline Guides (OAG), the total number of available seats increased from 320 million in 2008 to 802 million in 2017, and it is expected that China will displace the US as the world's largest aviation market by 2022 [10]. In spite of the remarkable growth of the Chinese aviation market in the past and its bright long-term prospects, this growth has been unbalanced, with the majority of growth coming from the domestic routes because of the partial deregulation of the aviation market [11]. In contrast to the US and European countries, where liberalization started fully with more extensive international air networks, more market power, financial resources, and larger fleets, Chinese airlines have little market power internationally, and the number of international air travel accounts for a much smaller portion of the whole of China's aviation market $[7,12]$. Air travel figures show that domestic seat capacity has risen from 242 million a decade ago to 629.2 million in 2017, whereas International seat capacity has risen from 78 million to 172.8 million over the same period [10].

Up to 2013, international air routes and cities with international aviation airports in China increased from 133 and 22 in 2000 to 507 and 50 by 2013. Currently, with the implementation of the Belt and Road Initiative (BRI). The point-to-point pattern of air travel is able to largely reduce the spatial-temporal constraints and increase the functional proximity of regions. Therefore, in order to realize the integration of BRI countries, airport and airline network constructions are the primary consideration in the BRI plan. The central government of China aims to invest extensive financial resources in the construction of international airports and airline networks in "Silk Road" countries to facilitate the interaction between China and other countries in Europe and Asia [13,14]. As a result of this large-scale international cooperation plan, the International Air Transport Association (IATA) even shifted its expectations about the center of gravity of world air travel eastward, away from the US and Europe in its 2017 annual report [15]. Although the market share of China's international aviation market of the total aviation market is still relatively small (10.4\%) compared to the US (23.2\%) and Europe (84\%), its international air networks are expanding rapidly. Therefore, unraveling the evolution of China's international air networks will be useful in helping us understand how China has been involved in the global market in the past. With that knowledge, the airlines, airports, and regulators can be better prepared for the future.

In recent years, quite a few studies have been dedicated to China's aviation market. Some research has tried to explain the policy impact on China's domestic aviation market and the evolution of the spatial structure of Chinese domestic airline networks. For instance, based on significant policy changes, Zhang and Chen [16] and Wang et al. [7] examined developments in the Chinese domestic airline industry and reform progress by dividing the whole progress into different phases. Zhang [9] and Jin et al. [17] mentioned that the impact of economic reform in the 1980s pushed the Chinese domestic aviation industry forward from a semi-military entity fully regulated by the Civil Aviation Administration of China (CAAC) to state-owned airline companies, which were formed with less profit-driven concern. However, during the process of partial deregulation between 1988 and 2004, China's aviation market was increasingly deregulated by the CAAC and changed from a state-owned sector to a profit-seeking one after the consolidation in 2002 [18]. Shaw et al. [8] compared the network structure of the domestic aviation market before and after the consolidation in 2002 and found that the current network structure of China's aviation system was preliminarily shaped. Wang et al. [7] recently further summarized the current Chinese domestic aviation market as characterized by state-led consolidation and privatization, with new private airline companies entering the market. Regarding the significant policy impacts on the Chinese domestic market, some studies have used complex network theory to identify details of the spatial structural development of Chinese domestic air networks with time schedule data (frequency of flights and scheduled seats) $[19,20]$. While the aforementioned studies have provided important insights on the influence of the policy issues and evolution of domestic Chinese airline networks, none of them has offered a different perspective on the international 
connection of China's aviation industry from the perspectives of policy changes and spatial evolution. The reasons for this are: (1) Compared to the US and Europe, in recent decades China's market share of the global aviation market has been rather small. (2) The large-scale expansion of China's international air networks happened only after China's active participation in the global market in the 2000s (Before the 2000s, the CAAC imposed strict restrictions on the number of designated airlines, routes operated, capacity, and frequency offered, which ultimately resulted in limited traffic rights between China and the rest of the world [21]). Up to now, only a few studies have focused on the international connection of the Chinese aviation market. Chang et al. [22] investigated changes in airline networks when direct flights between Taiwan and mainland China were allowed. Some researchers have also pointed out that as a result of the consolidation scheme, the international competitiveness of Beijing, Shanghai, and Guangzhou as international airline hubs has increased [21,23]. However, those studies focus only on a specific year or only a few major first-tier international airport cities, rather than the dynamics of a whole Chinese international aviation market from the perspective of policy changes. With the input of the numbers of actual O/D (origin/destination) air passengers from 1990 to 2013, this paper aims to fill this gap by conducting research on the characteristics of the development of Chinese international aviation and the relevant determinants.

The rest of this paper is organized as follows: Section 2 reviews the development of Chinese international aviation in a global context. Section 3 analyzes the potential determinants for the development of Chinese international aviation. The last section provides a summary and conclusion.

\section{The Historical Development of China's International Aviation Markets}

China's international air networks date back to the 1930s when the Republic of China governed the administration of air travel. The rapid development of China's international air networks started after the 1990s when the CAAC issued four policies for the reform of China's aviation market (By 2002, the CAAC had introduced four major policies for China's aviation market: consolidation of airline companies, deregulation in airfares, deregulation of entry and exit, and privatization [18]). In this paper, the development of China' international aviation market is divided into three stages, which reflect key regulatory measures introduced by the Central Government of China.

\subsection{The Start of China's International Aviation Markets (1937-1990)}

\subsubsection{Pre-PRC Era}

In 1936, during the reign of the Republic of China (1920-1949), the country opened its first international air route between Guangzhou and Hanoi in Vietnam. However, after the "Lugouqiao Incident" on July 7, 1937, when Japan launched its invasion of China, international air routes had almost been shut down. As a consequence of the War of Resistance Against Japan (1937-1945) and the Civil War of China (the "Liberation War" 1945-1949), only three international air routes were operational-between China and India, the Philippines, and the US—before the foundation of the People's Republic of China in 1949 [24].

\subsubsection{Pre-Reform ERA (1949-1978)}

Between 1950 and 1978, the process of opening international routes was still slow, even though China established international air routes with the Soviet Union, Japan, France, and some South-East and West Asian countries. The major reasons for this slow development were: (1) The incumbent Chinese Government, the People's Republic of China, was not fully recognized by the United Nations until 1971, so China did not establish diplomatic relations with most Western countries. (2) Mao Zedong's Cultural Revolution from 1966 to 1976 led to China's isolation from the international world [17]. Therefore, before economic reform in 1978, China was still not very involved on the international stage. There were only 12 international air routes to 13 countries, covering a total distance of only 55,342 km [25]. 


\subsubsection{Post-Reform ERA (1978-1990)}

After the economic reform in 1978 up to 1990, China started its partial deregulation process in the aviation market in order to meet the international world's expectations. In the 1980s, the CAAC became independent from military control and was fully responsible for controlling China's aviation market. With the implementation of several reform measures, including the separation of the management of airlines and airports from the CAAC central office, transforming airlines to profit-driven business entities, and encouraging competition, the CAAC allowed domestic airline companies in China to operate more international routes [8,17]. Up until 1984, there were 19 countries with 24 international air routes with China, and the total distance increased to 100,800 km [25].

It can be concluded that the first phase of the development of China's international aviation market was rather slow.

\subsection{The Formation of China's International Air Networks (1990-2000)}

From the beginning of the 1990s, China's international aviation market embraced the global market with more effort after the deregulation process on market entry and route entry [8]. In 1996, China's airports were registered in the system of the International Civil Aviation Organization (ICAO), and Hainan province was allowed to open the third, fourth, and fifth freedom of the air, while Xiamen and Nanjing expanded the fifth freedom of the air. This signified that China's aviation market started to relax its aviation market entry criteria for foreign countries. Meanwhile, China's "Big Three" airline companies (Air China, China Southern, and China Eastern) signed a code-sharing contract with international airline companies (United Airlines, Japan Airlines), which meant more route entries for foreign airline companies would be realized in China $[25,26]$. With the easy approval of market and route entry, Table 1 indicates that the number of international air routes and cities with international aviation airports in China increased from 44 and 9 in 1990 to 133 and 22 by 2000 (a two-fold and 1.4-fold growth). During the same period, the number of foreign countries and cities with international air travel with China grew from 24 and 32 to 33 and 56 (a 0.4-fold and a 0.9-fold growth). Meanwhile, $56.3 \%$ of the newly added foreign cities with international air travel with China in 2000 were still located in the 23 foreign countries with international connections with China in 1990. This means China's international aviation markets not only expanded their networks to new territories, but also consolidated its networks on the existing international market. In the meantime, when China's international aviation markets quickly expanded their new networks, the major connections of international routes were centralized in the national capitals of both China and foreign countries, except for the international route between Shanghai and Auckland. Furthermore, the annual number of international air passengers between 1990 and 2000 increased from 1.09 million to 6.24 million-an annual growth rate of $19.1 \%$ (Figure 1), which was much faster than the global growth rate $(5.5 \%)$. In addition, China's market share of international aviation rose from $1.7 \%$ to $6.0 \%$. During this phase, with the deregulation process in China, the formation of China's international air networks had been formed, which provided a solid basis for exponential growth in the next phase. 
Table 1. The development of China's international aviation transportation, 1990-2016.

\begin{tabular}{cccccccccc}
\hline Categories & $\mathbf{1 9 9 0}$ & $\mathbf{1 9 9 5}$ & $\mathbf{2 0 0 0}$ & $\mathbf{2 0 0 5}$ & $\mathbf{2 0 1 0}$ & $\mathbf{2 0 1 3}$ & $\mathbf{2 0 1 4}$ & $\mathbf{2 0 1 5}$ & $\mathbf{2 0 1 6}$ \\
\hline International air routes & 44 & 85 & 133 & 233 & 302 & 427 & 490 & 660 & 739 \\
\hline The freq. of international airlines & 7216 & 17,278 & 36,909 & 92,852 & 147,488 & 243,541 & - & - & - \\
\hline $\begin{array}{c}\text { Foreign countries with international } \\
\text { air travel with China }\end{array}$ & 24 & 31 & 33 & 33 & 54 & 50 & 48 & 55 & 56 \\
\hline $\begin{array}{c}\text { Cities with international aviation } \\
\text { airports }\end{array}$ & 9 & 14 & 22 & 27 & 33 & 50 & 51 & 51 & 77 \\
\hline $\begin{array}{c}\text { Foreign cities with international } \\
\text { travel with China }\end{array}$ & 32 & 51 & 56 & 72 & 101 & 126 & 125 & 137 & 146 \\
\hline $\begin{array}{c}\text { International air passengers } \\
(\mathbf{1 . 0} \times \mathbf{1 0} \mathbf{4} \text { persons) }\end{array}$ & 108.7 & 313.3 & 624.1 & 1343.5 & 2257.8 & 3118 & 3155 & 4207 & 5162 \\
\hline International air cargos (1.0 $\times \mathbf{1 0} \mathbf{4} \mathbf{t})$ & 7.5 & 17.4 & 45.0 & 76.4 & 185.5 & 176.0 & 168.4 & 186.8 & 193.2 \\
\hline$\quad$ N
\end{tabular}

Note: Freq. means frequency and the freq. of international airlines from 2014 to 2016 are not available.

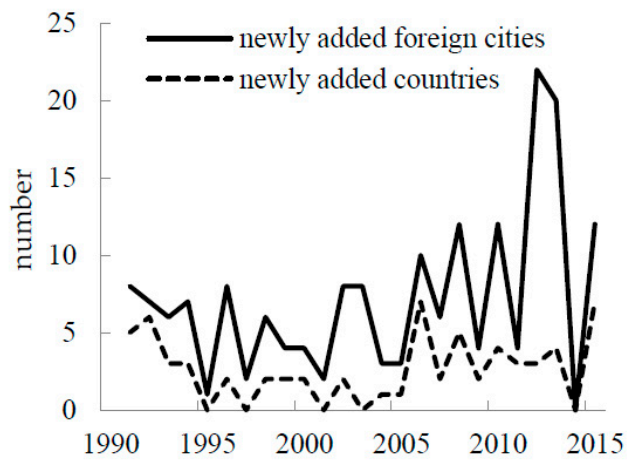

(a)

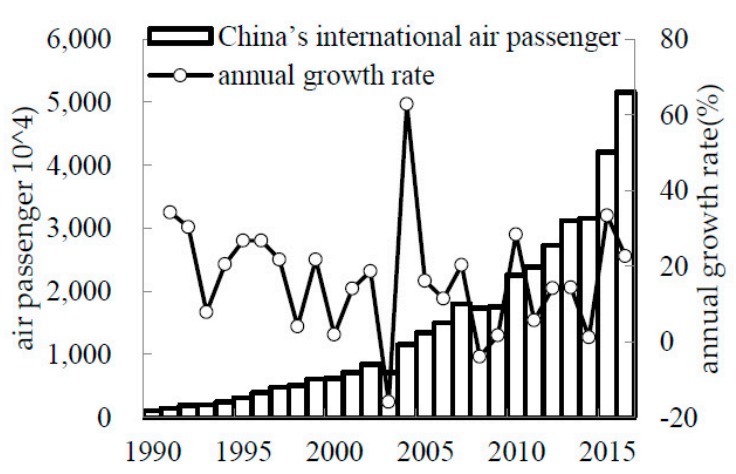

(b)

Figure 1. The number of newly added foreign cities and countries with international air travel with China (a), and China's international air passenger traffic (b), 1990-2016.

\subsection{The Rapid Expansion of China's International Air Networks (2001-Present)}

From the beginning of the twenty-first century, China's international air networks experienced exponential growth due to a few core policy changes in the aviation industry in the very broad perspective on "opening up" [7]. In 2001, China's participation in the World Trade Organization (WTO) pushed forward the demand for international travel and largely dissolved the existing barriers to international trade and travel between China and Western countries [27]. As a result, international airline companies acquired more opportunities for entering the Chinese market. In order to achieve economies of scale and face the challenges from foreign airline companies, the implementation of the state-led consolidation in 2002 merged all state-owned airline companies into three major airline groups: China National Aviation Holding Company (core business is Air China), China Eastern Air Holding group (core business is China Eastern Airlines), and China Southern Air Holding group [8]. After the consolidation, three state-owned airline groups became fully independent from the CAAC and increased their competitiveness in the global market. Besides, due to the experimental deregulation and privatization of private airline companies, private Hainan Airlines also made several acquisitions and mergers in 2001 through US investments and public stock offerings in China [17]. After that, Hainan Airlines opened the first international air route from Sanya to Seoul by a private airline company. Moreover, in 2004, China signed a contract "Sino-US Expansion of Aviation Services Agreement" with the US, which further stimulated the opening of the Chinese aviation market to foreign aviation companies after the consolidation. In 2012, the central government of China published its new international travel policy "The relaxation of the operation of China's airlines and the entry of South-Eastern Asian countries' airlines." This policy largely liberated international air travel between China and the Association of Southeast Asian Nations (ASEAN) countries, most airport cities in Japan 
(with the exception of Tokyo, Osaka, and Nagoya, Jiju in Korea, and Saiban and Guam in the US). Recently, with the potential impact of BRI, as mentioned in the introduction, the increased international connections between China and the "Silk Road" countries facilitated international air travel to a large extent. In addition, with the rapid urbanization and increasing purchasing power of people in the past decade, Chinese citizens intended to go abroad for leisure activities (tourism, shopping, and family visits), which provided a considerable amount of potential passengers for China's international aviation markets [28]. Due to the "opening up" policy changes on the Chinese aviation market, up to 2016, international air routes and cities with international aviation airports in China increased from 133 and 22 in 2000 to 739 and 77 by 2016 (Table 1) (a 4.6-fold growth and a 2.5-fold growth, respectively). During the same period, the numbers of foreign countries and cities with international air travel with China grew from 33 and 56 to 56 and 146 (a 0.75-fold growth and a 1.6-fold growth, respectively). Meanwhile, $62.5 \%$ of the newly added foreign cities with international air travel to China in 2013 were still located in the 32 foreign countries already with international air connections to China in 1990. This means that in the third phase, China's international air networks aimed at consolidating the previous international aviation market, which was different from the second phase. However, in the same way as the second phase, the major connections of international routes were centralized in the national capitals of both China and foreign countries. Meanwhile, the annual number of China's international air passengers, increased from 6.2 million in 2000 to 51.62 million in 2016, with an annual growth rate of $14.2 \%$ (Figure 1 ).

\section{The Evolution of China's International Air Networks}

In this paper, we used O/D passenger flow data to understand the evolution of China's international air networks. China's international air networks are defined as the routes operated by China's airline carriers/companies for international travel between China and other countries. The data were sourced from the databases of the CAAC $(1990,2013)$. The actual O/D passenger flow data can more accurately depict the spatial structure of the evolution of China's international networks as to their true origins and destinations [29]. For example, if there is a transfer between two countries, the city of the starting country and the city of the destination country are reserved, such as combining Beijing-Dubai-Luanda route into Beijing-Luanda. Previous supply of demand data would consider the whole trip as two parts, which could underestimate the connectivity of domestic cities to the international cities. Thus, while previous supply of demand data may be useful for assessing the effects of people as air passengers (e.g., boosting demand for baggage handling services), the actual O/D network is more useful for assessing the effects of people as visitors that engage with the local area (e.g., boosting demand for non-transportation services in the destination city [30]. Air transport data in 1990 were the earliest data available for examining China's international air networks in the second phase of the development of China's international aviation markets. In 2013, they were the most recent data available to get the most updated overview of China's international air networks in the third phase. The airline consolidation implemented by the CAAC in 2002 caused profound changes in China's aviation markets. Therefore, 2000 and 2005 are also considered in the analysis. For those with multiple airports, the data are combined with one entry for each city. The O/D data contains 44 airline routes, 7216 frequency of flights and 1.087 million airline passengers in 1990, and 507 airline routes, 243,541 frequency of flights and 31.18 million airline passengers in 2013.

\subsection{The Spatial Distribution of China's International Air Networks}

\subsubsection{Connected International Cities and Regions}

In Figure 2, from 1990 to 2013, foreign cities with international travel to and from China were located mostly in Asia (more than 50\%) and then Europe (23\%-35\%). Meanwhile, Japan had the largest number of foreign cities with international air travel with China, whereas most cities affected by China's international air travel shutdown in 2013 were located mainly in West Asia and Europe. 
In Table 2, although the opening rate of foreign cities with international air travel with China after 2000 was generally fast, it differed from continent to continent (The opening rates of foreign cities with international air travel links with China means the ratio of foreign cities with international air travel links with China to foreign cities with international air travel). Between 1990 and 2013, the opening rate of foreign cities with international air travel with China was much higher in the Asian market, with a decreasing speed of growth than the Oceanian market, which was growing increasingly fast. In contrast, the opening rates of foreign cities with international air travel with China in North America and Europe were still quite low. After 2000, China started its international air routes with Africa and South America, and by 2013, the opening rates of foreign cities with international air travel links with China on these two continents were 3.6\% and 1\%, respectively. By 2013, foreign cities with international air travel links with China were located mainly in Asian countries (Japan, Korea, and Thailand). The opening rates of foreign cities with international air travel links with China in Korea and Thailand were more than $60 \%$, which was higher than any other country. Then followed the opening rates of foreign cities with international air travel links with China, such as Japan, Russia, and Australia. These opening rates were more than $35 \%$.

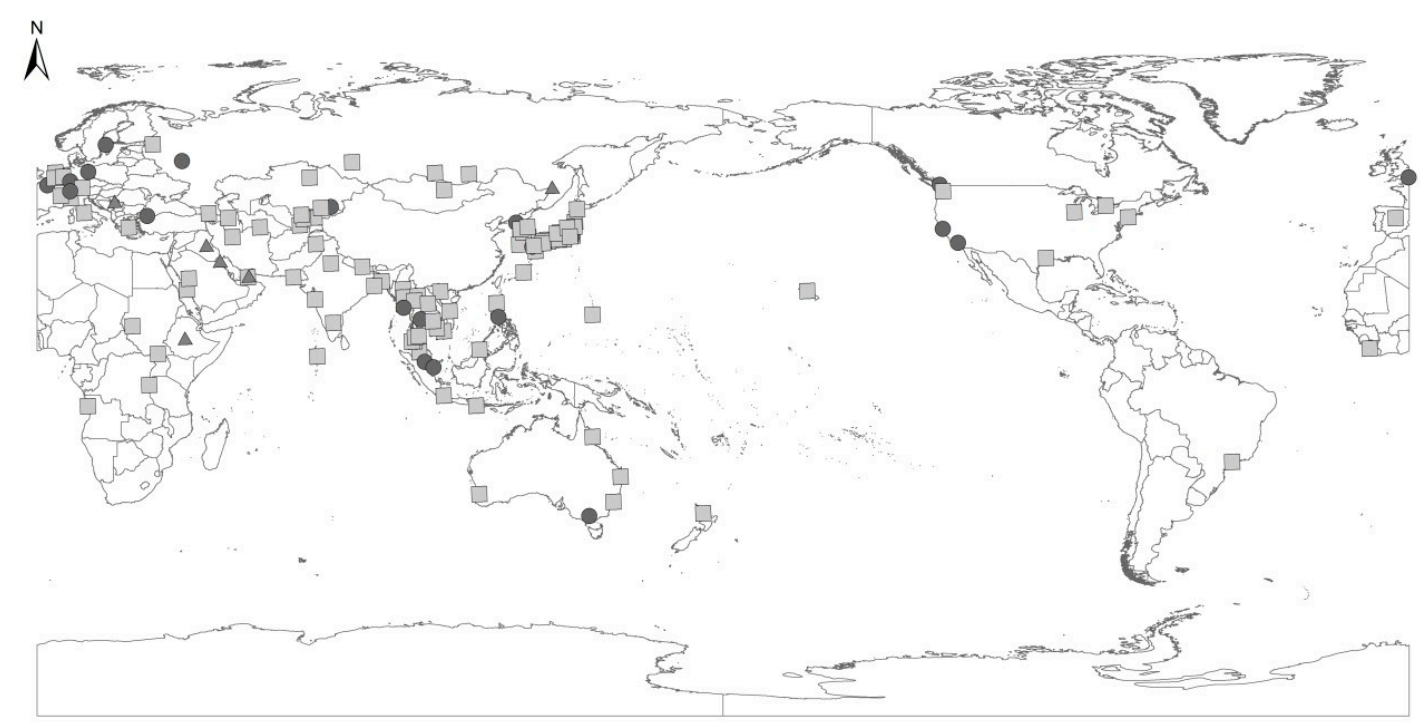
$\begin{array}{cc}0 & 2000 \mathrm{~km} \\ 1 & \mathrm{I}\end{array}$
- foreign cities with international air linkages with China in both 1990 and 2013
- foreign cities with international air linkages with China in 2013 but not in 1990
॥ foreign cities with international air linkages with China in 1990 but not in 2013

Figure 2. Spatial distribution of foreign cities with international air links with China in 1990 and 2013.

Table 2. The opening rate of China's international air network in six continents (\%), 1990-2013.

\begin{tabular}{|c|c|c|c|c|c|c|}
\hline & $\begin{array}{c}\text { Foreign Cities with } \\
\text { International Air } \\
\text { Travel with China } \\
\text { in } 1995\end{array}$ & $\begin{array}{l}\text { Opening } \\
\text { Rate }(\%)\end{array}$ & $\begin{array}{c}\text { Foreign Cities with } \\
\text { International Air } \\
\text { Travel with China } \\
\text { in } 2000\end{array}$ & $\begin{array}{l}\text { Opening } \\
\text { Rate }(\%)\end{array}$ & $\begin{array}{c}\text { Foreign Cities with } \\
\text { International Air } \\
\text { Travel with China } \\
\text { in } 2013\end{array}$ & $\begin{array}{l}\text { Opening } \\
\text { Rate }(\%)\end{array}$ \\
\hline Asia & 23 & 39.0 & 34 & 34.0 & 80 & 32.4 \\
\hline Oceania & 2 & 13.3 & 3 & 17.6 & 6 & 23.1 \\
\hline $\begin{array}{c}\text { North } \\
\text { America }\end{array}$ & 5 & 4.7 & 5 & 3.9 & 11 & 6.8 \\
\hline Europe & 14 & 5.7 & 14 & 5.0 & 23 & 5.0 \\
\hline Africa & 0 & 0 & 0 & 0 & 5 & 3.6 \\
\hline $\begin{array}{c}\text { South } \\
\text { America }\end{array}$ & 0 & 0 & 0 & 0 & 1 & 1.0 \\
\hline $\begin{array}{l}\text { Average } \\
\text { number }\end{array}$ & 44 & 8.6 & 56 & 8.5 & 126 & 11.1 \\
\hline
\end{tabular}

Table 3 shows that Seoul replaced Tokyo as the first-ranked foreign city with international air travel ties with China with regard to the annual number of international air passengers. The percentage 
of accumulated international air passengers of the top ten cities decreased from $81.0 \%$ in 1990 to $53.0 \%$ in 2013, while the number of political capital cities decreased from six to four. However, between 1990 and 2013, the ranking of international economic centers such as Sydney, San Francisco, and international tourism cities such as Phuket and Jeju advanced to the top ten. This means that with the increasing purchasing power of Chinese citizens during this time, the major purpose of international air travel changed from public service obligations to leisure and recreational activities, indicating that those political centers would be less attractive than the economic and tourism centers in China's international air networks.

Table 3. Top 10 cities with international air travel with China 1990-2013.

\begin{tabular}{|c|c|c|c|c|c|c|c|c|c|}
\hline Rank & 1990 & $\operatorname{Pax}$ & $\begin{array}{c}\text { Percentage } \\
(\%)\end{array}$ & 2000 & $\operatorname{Pax}$ & $\begin{array}{c}\text { Percentage } \\
(\%)\end{array}$ & 2013 & Pax & $\begin{array}{c}\text { Percentage } \\
(\%)\end{array}$ \\
\hline 1 & Tokyo & 289,928 & 26.7 & Seoul & 824,188 & 13.2 & Seoul & $4,180,138$ & 13.4 \\
\hline 2 & Osaka & 138,377 & 12.7 & Tokyo & 637,780 & 10.2 & Bangkok & $2,880,578$ & 9.2 \\
\hline 3 & San Francisco & 104,173 & 9.6 & Singapore & 618,997 & 9.9 & Singapore & $2,385,773$ & 7.7 \\
\hline 4 & Singapore & 87,762 & 8.1 & Osaka & 505,087 & 8.1 & Tokyo & $1,467,716$ & 4.7 \\
\hline 5 & Bangkok & 81,961 & 7.5 & Bangkok & 459,019 & 7.4 & Osaka & $1,270,192$ & 4.1 \\
\hline 6 & Fukuoka & 48,035 & 4.4 & Los Angeles & 389,874 & 6.2 & Phuket & 941,823 & 3.0 \\
\hline 7 & Frankfurt & 38,347 & 3.5 & Nagoya & 335,806 & 5.4 & Los Angeles & 920,871 & 3.0 \\
\hline 8 & Paris & 32,604 & 3.0 & Fukuoka & 318,113 & 5.1 & Sydney & 891,433 & 2.9 \\
\hline 9 & London & 30,559 & 2.8 & Paris & 209,700 & 3.4 & Nagoya & 856,924 & 2.7 \\
\hline 10 & Manila & 29,556 & 2.7 & Frankfurt & 199,313 & 3.2 & Jeju & 732,070 & 2.3 \\
\hline Total & & 881,302 & 81 & & $4,497,877$ & 72.1 & & $16,527,518$ & 53 \\
\hline
\end{tabular}

Note: Pax means passengers.

\subsubsection{Connected International Routes}

Figure 3 shows that the destinations of international air passengers tended to be located mainly in specific regions and cities. In 1990, three core regions were dominant for their role in attracting international air passengers: East Asia, with Tokyo and Osaka as the dominant cities, Europe, with Frankfurt, Paris, and London as the dominant cities and South-East Asia, with Singapore and Bangkok as the dominant cities. In terms of international air routes, Shanghai-Tokyo, Shanghai-Osaka, and Shanghai-San Francisco recorded passenger flows exceeding 100,000 per year. The three core regions of the 1990s remained the major focus of China's international air travel in 2013. In fact, the international aviation markets of the three regions expanded significantly. In addition, the growth rates of international air passengers and international air routes in East Asia and South-East Asia were the largest compared to other areas. Among them, the Shanghai-Bangkok, Shanghai-Seoul, Shanghai-Tokyo, Shanghai-Osaka, Guangzhou-Bangkok, and Beijing-Seoul routes handled more than 600,000 passengers. This is reasonable since East and South-East Asia are proximate to China and have close international business ties, which has facilitated international air travel between them.

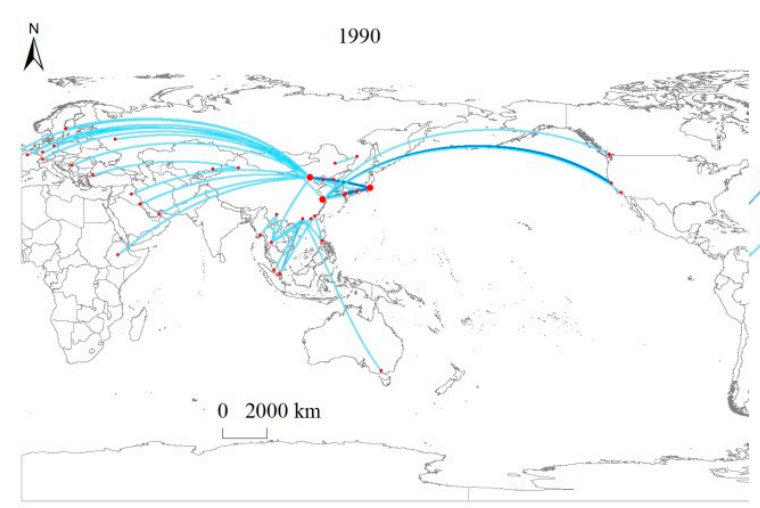

(a)

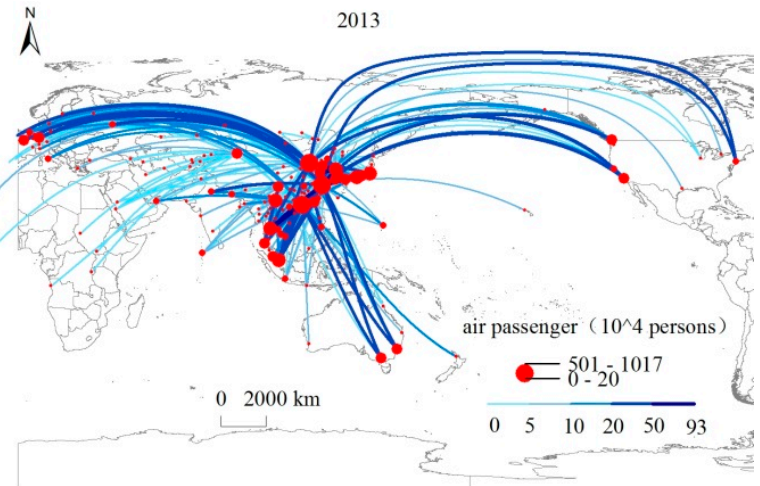

(b)

Figure 3. Spatial distribution of China's international air passenger linkages, 1990 (a)-2013 (b). 


\subsection{The Clustering Characteristics of International Air Passengers}

To understand how China's international air passengers are clustered, we used the percentage of accumulated passenger flows as the $\mathrm{Y}$-axis and the accumulated percentage of international routes as the $\mathrm{X}$-axis. Figure 4 indicates that the distribution of international air passengers follows a logarithmic distribution $(y=\operatorname{aln}(x))$, and $60 \%$ of international air passengers were centralized in $20.5 \%$ of international air routes in 1990, in $21.1 \%$ of international air routes in 1995, in $22.5 \%$ of international air routes in 2000, in $20.6 \%$ of international air routes in 2005, in $17.7 \%$ of international air routes in 2010, and in $16.2 \%$ of international air routes in 2013. This means that, in the long run, most of China's international air passengers would be centralized in only a small number of international routes. In addition, the parameter $a$ first increased from 24.972 in 1990 to 25.335 in 2000, and then decreased to 24.027 in 2005, to 22.774 in 2010, and to 22.589 in 2013 (Table 4). This means the whole international air networks first experienced a flattering gradient, and thus declining dominance of top international air routes between 1990 and 2000, and then a reverse trend of increasing dominance of top international routes between 2000 and 2013.

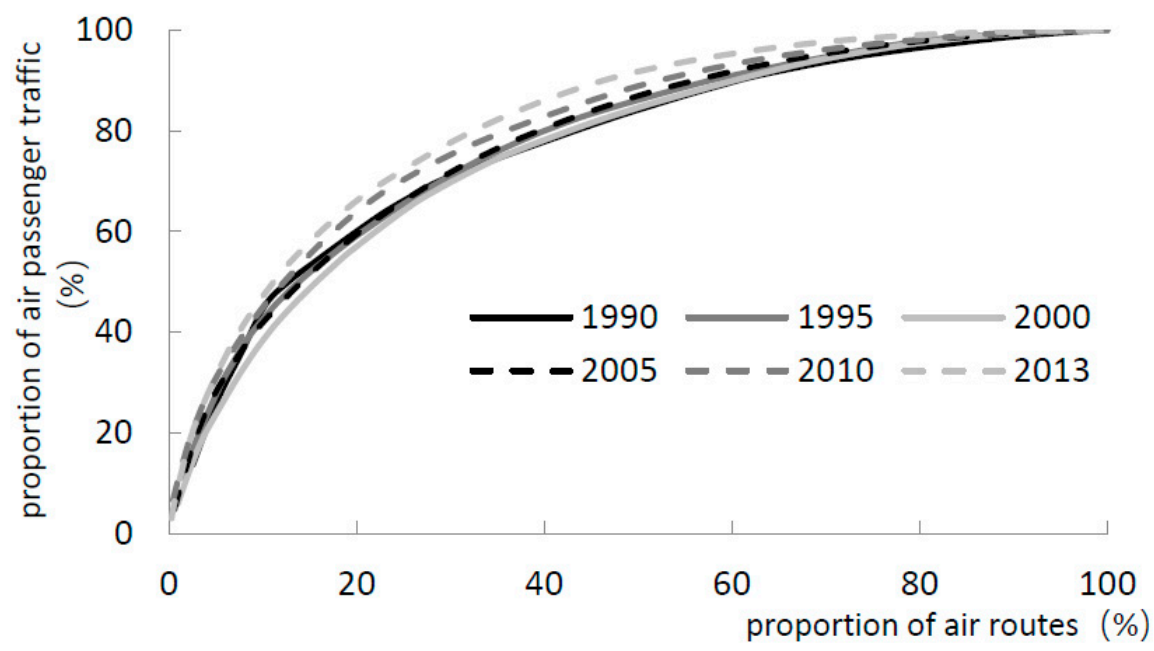

Figure 4. Rank-size distribution of air passenger traffic on China's international air routes, 1990-2013.

Table 4. Equation of accumulated passenger and accumulated percentage of international routes.

\begin{tabular}{cc}
\hline Year & Equation \\
\hline 1990 & $\mathrm{y}=24.972 \ln (\mathrm{x})-13.569, \mathrm{R}^{2}=0.9978$ \\
1995 & $\mathrm{y}=24.579 \ln (\mathrm{x})-11.195, \mathrm{R}^{2}=0.9881$ \\
2000 & $\mathrm{y}=25.335 \ln (\mathrm{x})-15.236, \mathrm{R}^{2}=0.9813$ \\
2005 & $\mathrm{y}=24.027 \ln (\mathrm{x})-8.6944, \mathrm{R}^{2}=0.9795$ \\
2010 & $\mathrm{y}=22.774 \ln (\mathrm{x})-2.1723, \mathrm{R}^{2}=0.9801$ \\
2013 & $\mathrm{y}=22.589 \ln (\mathrm{x})+0.2572, \mathrm{R}^{2}=0.9763$ \\
\hline
\end{tabular}

Figure 5 further confirms that from 1990 to 2013, Asia was the destination that accommodated the most of China's international air passengers, in contrast to Africa and North America, which were the destinations with the least number of international air passengers. Furthermore, regarding the number of international passenger flows in Asia, more than 34\% were located in East Asia, $20 \%-30 \%$ were in South-East Asia, and less than $6 \%$ were in West, Middle, and South Asia. Meanwhile, Korea, Thailand, Japan, the US, and Singapore were major destinations for international air passengers, while Korea replaced Japan in 2013 as the most attractive destination for international air passengers. 


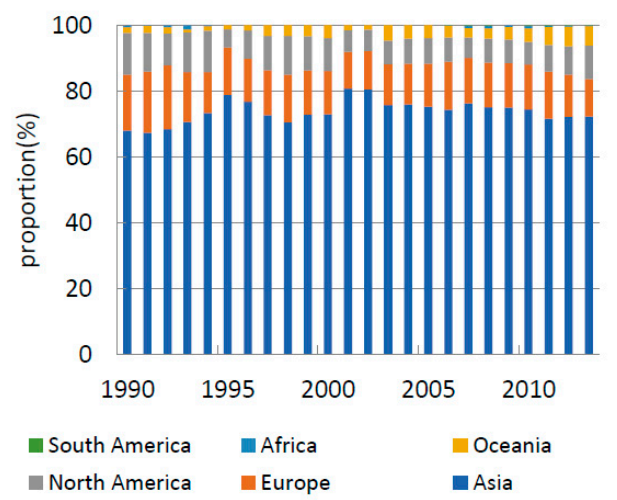

(a)

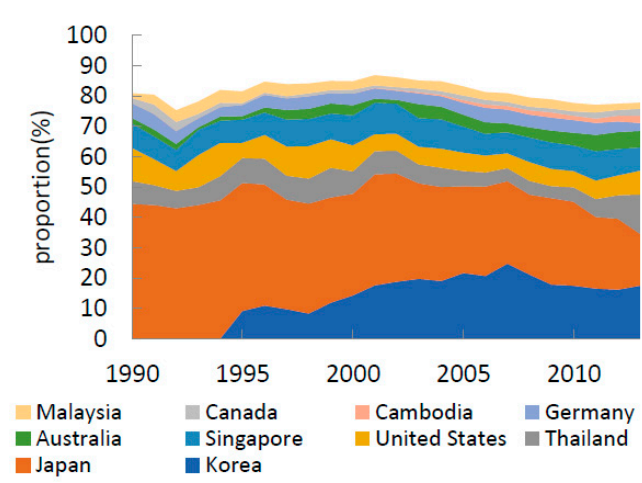

(b)

Figure 5. The proportion of air passenger traffic between China and six continents (a) vs. countries (b), 1990-2013.

\section{The Potential Determinants for the Evolution of China's International Air Networks}

\subsection{Average International Air Travel Distance}

Based on air passenger flow data and the flight distance of international air routes (Figure 6), from 1990 to 2013, the average international air travel distance decreased from $7017.4 \mathrm{~km}$ to $5097 \mathrm{~km}$. This means the rule of distance decay in air traffic was more applicable in 2013 than in 1990. It also means that the extension of China's international air networks was focused more on areas with proximity to China for short- and medium-haul travel. In addition, more than $80 \%$ of international air passengers were located in three categories: (1) $500-4000 \mathrm{~km}$, (2) $11,500-13,500 \mathrm{~km}$, and (3) $26,500-27,500 \mathrm{~km}$. This reflects the diversity of the areas covered by China's international air travel. Moreover, the percentages of international air routes and air passengers of the first category are more than $50 \%$ and $65 \%$, respectively. In this travel distance (500-4000 km), foreign cities that had international air travel links with China were located mainly in South and South-East Asia. They included Seoul, Bangkok, Osaka, Phuket, Jeju, Singapore, Tokyo, Osaka, and Busan.

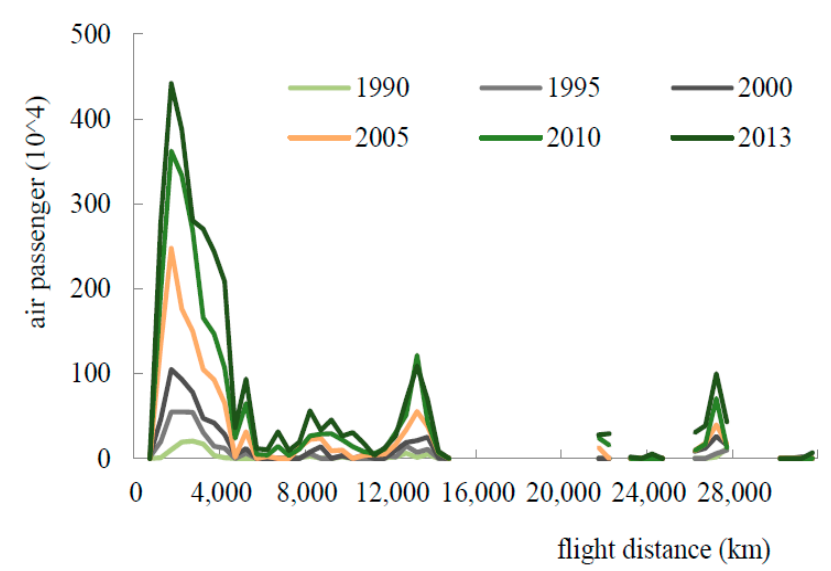

Figure 6. International air passenger distribution of flight distance, 1990-2013.

\subsection{Institutional and Policy Changes}

The progressive evolution of China's international air networks was the result of institutional and policy changes in China's international markets. After the economic reform, China opened its gateway to the world and actively participated in the global market, which largely facilitated the international connection between China and other countries and opened up the post-reform era of the first stage of the historical development of China's international aviation market. Therefore, the Chinese government set up specific institutional and policy changes so China could become more 
involved in the global market. First, international deregulation on the aviation market stimulated China's deregulation progress, even though it was not fully completed, compared to the US and Europe, which to some extent pushed Chinese domestic aviation industry forward from a semi-military entity fully regulated by the CAAC to state-owned airline companies. In order to embrace the trend of international liberalization, the CCAC declared its international aviation market in a "proactive, progressive, orderly and safeguarded" manner, and proceeded to take a proactive attitude [31]. As a result of the liberation process, a large number of Air Service Agreements (ASA) and, importantly, higher freedoms of traffic rights were signed between China and other countries, which fundamentally contributed to the development of China's international air travel (Figure 7). For instance, by 2016, China signed partner distribution of ASAs with 118 countries [32]. That largely facilitated the formation of the second stage and the expansion of the third stage of China's international aviation market. Moreover, after 1990, when China and Korea increasingly improved the liberation of market and route entry, both countries agreed to the opening of the third and fourth freedom of traffic rights by 2010 [33]. This progress started China's rapid international aviation expansion in its major Asian market. Until the end of 2013, Korea has been the country with the most international air travel with China, which further replaced Japan as the most attractive destination for international air passengers as mentioned above. Up to the end of 2015, China opened the fifth freedom of traffic rights with 11 international cities. Compared to the third and fourth freedoms of traffic rights, China's airline companies were able to extend their international air networks because of more freedom on the market and route entry between China and other countries. As a consequence, China's "Big Three" airline companies could establish more route entries for foreign airline companies for the expansion of China's international air networks. Second, the policy change on visas for international travel provided further impetus for the rapid growth of international air travel. With the increasing travel demand for international tourism and the purchasing power of Chinese citizens, many international countries resorted to a more convenient entry and exit policy for Chinese tourists by signing a "visa waiver" or "visa on arrival" contract with China. By the end of 2015, 50 countries had built up a diplomatic relationship with China, in which there was a "visa waiver" or "visa on arrival" policy with China, and those countries became the most attractive international destinations for Chinese tourists. Especially, international tourist cities in Asian market mentioned in Section 3 such as Phuket and Jeju have become the most attractive destination for China's international airline networks. For instance, after 2002, when Jeju Island signed the "visa waiver" contract with China, the number of international routes from Jeju to China increased to 13, and the number of air passengers was more than 730,000 in 2013. Third, with the recent deployment of BRI, China's airline companies increased the frequency of direct flights between China and South-East Asia, Europe, and Africa to satisfy the national policy of improving the interaction between China and other countries in Europe and Asia [13,14].

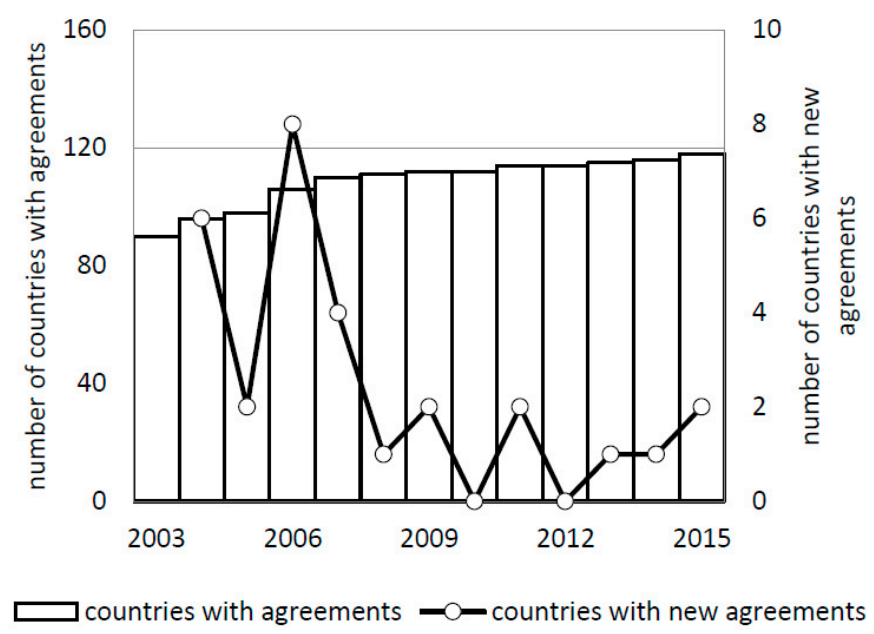

Figure 7. The number of countries with bilateral air services agreements with China. 


\subsection{Increasing Foreign Trade and Foreign Tourism}

After China joined the WTO, foreign trade and foreign tourists between China and other countries increased significantly. On the one hand, since the early 1990s, China has adopted an export-oriented development strategy, and connecting important international markets by air has been a top priority for the CAAC [21]. In 2011 China's exports and imports accounted for global shares of more than $10 \%$ and $9.5 \%$, respectively. These remained the largest and second-largest figures for imports and exports in the world for three consecutive years [34]. As mentioned by Graham [35], international travel is positively correlated with the growth of exports and imports. In the same time span, the number of China's international air passengers grew at around 13\%. Regarding the correlated growth between international trade and international air passengers, Liu and $\mathrm{Hu}$ found there was a causal relationship between foreign trade and air transportation, and the contribution value was 0.28 [36]. On the other hand, between 1990 and 2014, the purchasing powering of Chinese citizens increased rapidly and largely stimulated the growth in the number of outgoing tourists (Figure 8). Meanwhile, the growth rate of incoming international tourists was around $11.7 \%$, and more than $50 \%$ chose airlines as the travel mode for international travel. In 2013, more than 75\% of international tourists from Sweden, Germany, Switzerland, Korea, the Netherlands, Japan, and Italy traveled to China by air. Both cases indicate that to meet the demand for international air transport required by the country's foreign trade and tourism sectors, China had to accelerate the development of its international air networks [31].

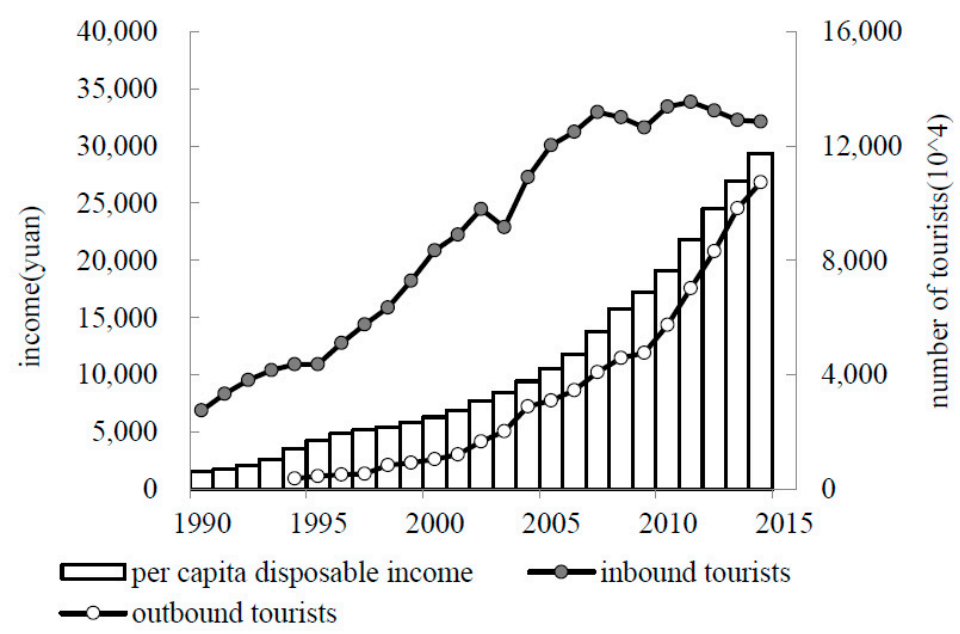

Figure 8. Per capita disposable income of China's urban residents and international tourists.

\section{Conclusions and Discussion}

China's international airline markets have experienced tremendous growth in the past two decades and are likely to continue the rapid expansion in the years ahead, thanks to the country's active participation in the global market in terms of a more open economy, international trade, and tourism [31,32]. To the best of our knowledge, this paper is the first to describe the historical development of China's international aviation market and use actual O/D international passenger flows to describe the evolution of the Chinese aviation market and its relevant potential determinants.

The historical development of China's international aviation markets can be divided into three phases: The start of international aviation markets (1937-1990), the formation of international air networks (1990-2000), and the rapid expansion of international networks. Doubtless, the deregulation process in China and China's "opening up" strategy in the global forum accelerated the expansion of China's international air networks after 1990 [9]. On the one hand, the development of China's international aviation networks tends to first connect the political capital of international countries. On the other hand, with the increasing purchasing power of Chinese citizens and the travel demands of international tourism, international economic and tourism centers have also become target destinations for air travelers from China. The core potential determinants can be attributed to the evolution of 
China's international air networks, average international air travel distance, institutional and policy changes, increasing foreign trade, and foreign tourism.

In terms of the average international air travel distance, the rule of distance decay is still applicable in the spatial distribution of China's international air networks. Overall, China's international air networks show an obvious clustering pattern for short- and medium-haul travel in Asia because of the proximity of East and South-East Asia to China. However, the region most connected by China's international airlines changed from East Asia to East and South-East Asia (countries such as Korea, Japan, Thailand, and Singapore). Moreover, in terms of institutional and policy changes, the international deregulation of the aviation market accelerated China's deregulation progress, which led to the signing of a large number of Air Service Agreements (ASA) and higher freedoms of traffic rights between China and other countries. The policy change regarding visas for international travel also stimulated the rapid growth of international air travel. With the implementation of BRI, China's international air networks expanded to the BRI countries in South-East Asia, Europe, and Africa to improve interaction with these countries. After China became actively involved in the global market, foreign trade and foreign tourism between China and other countries increased considerably, which resulted in increased demand for international air travel between China and other countries, thereby contributing to the fast expansion of China's international air networks.

With China's strong and rapid economic growth and its positive attitude toward globalization, the country is becoming a major player in global air transportation. Accordingly, it is important for the research community to study the economic, political, social, and geographic aspects of China's international air transportation. The Chinese government has made many institutional and policy changes and will continue to make changes to its international airline industry. Those experiences could be useful for those developing countries also with a fast development of international aviation markets. For example, the active participation in international trade at a global market could largely facilitate the expansion of international airline networks. Meanwhile, the certain level of relevant deregulated policy changes on the consolidation of three major airline companies could be applicable to the developing countries with monopoly airlines to be more liberal and competitive in the certain stage of aviation market development. Moreover, with the implementation of BRI, we predict that future China's international airline networks will be much more extended and focused on the connection of international airline cities in the east Europe and middle Asia with more middle and long-haul international air travel. There are interesting research questions waiting to be tackled. We hope this paper will encourage other researchers to pursue these and other interesting and challenging research questions. Compared to the developed countries, China's partial deregulation has stimulated the growth of the international aviation market. However, whether the partial deregulation is a better approach than full deregulation of the international air travel for China needs to be tested. In addition, with the strong growth of the Chinese economy, international trade, and the tourist market, China's international airlines will continue to enjoy strong growth in the medium to long term. Therefore, the ways in which China aims to achieve sustainable development, and how China's international airlines improve their competitiveness in terms of network configuration, cost efficiency, and service quality, will be crucial for the future development of China's international air transportation.

Author Contributions: Conceptualization: J.W. and H.Y.; Formal analysis: H.W.; Supervision: J.W.; Visualization: H.W.; Writing-original draft, J.W., H.Y., H.W.

Funding: This work is financially supported by the Strategic Priority Research Program of the Chinese Academy of Sciences (Grant XDA19040402), the National Natural Science Foundation of China (Grants 41722103) and the Key Laboratory of Regional Sustainable Development Modeling, Institute of Geographic Sciences and Natural Resources Research, Chinese Academy of Sciences (Grant KF2018-03).

Conflicts of Interest: The authors declare no conflict of interest. 


\section{References}

1. Derudder, B.; Witlox, F. Mapping world city networks through airline flows: context, relevance, and problems. J. Transp. Geogr. 2008, 16, 305-312. [CrossRef]

2. Allroggen, F.; Wittman, M.D.; Malina, R. How air transport connects the world - A new metric of air connectivity and its evolution between 1990 and 2012. Transp. Res. Part E Logist. Transp. Rev. 2015, 80, 184-201. [CrossRef]

3. Wandelt, S.; Sun, X. Evolution of the international air transportation country network from 2002 to 2013. Transp. Res. Part E Logist. Transp. Rev. 2015, 82, 55-78. [CrossRef]

4. Dobruszkes, F. Does liberalisation of air transport imply increasing competition? Lessons from the European case. Transp. Policy 2009, 16, 29-39. [CrossRef]

5. Bettini, H.F.A.J.; Oliveira, A.V.M. Airline capacity setting after re-regulation: The Brazilian case in the early 2000s. J. Air Transp. Manag. 2008, 14, 289-292. [CrossRef]

6. Koo, T.T.R.; Lohmann, G. The spatial effects of domestic aviation deregulation: a comparative study of Australian and Brazilian seat capacity, 1986-2010. J. Transp. Geogr. 2013, 29, 52-62. [CrossRef]

7. Wang, J.; Bonilla, D.; Banister, D. Air deregulation in China and its impact on airline competition 1994-2012. J. Transp. Geogr. 2016, 50, 12-23. [CrossRef]

8. Shaw, S.L.; Lu, F.; Chen, J.; Zhou, C. China's airline consolidation and its effects on domestic airline networks and competition. J. Transp. Geogr. 2009, 17, 293-305. [CrossRef]

9. Zhang, A. Industrial reform and air transport development in China. J. Air Transp. Manag. 1998, 4, $155-164$. [CrossRef]

10. Oman Aviation Group (OAG). OAG Take-Off: Essential Metrics on the World's Major Airline; Oman Aviation Group: Luton, UK, 2017.

11. Fu, X.; Zhang, A.; Lei, Z. Will China's airline industry survive the entry of high-speed rail? Res. Transp. Econ. 2012, 35, 13-25. [CrossRef]

12. Zhang, Q.; Yang, H.; Wang, Q.; Zhang, A. Market power and its determinants in the Chinese airline industry. Transp. Res. Part A Policy Pract. 2014, 64, 1-13. [CrossRef]

13. Wang, J.; Wang, H.; Jiao, J. China's international aviation transport to the Belt and Road Initiative area. Prog. Geogr. 2015, 34, 554-562.

14. Liu, W.; Dunford, M. Inclusive globalization: unpacking China's Belt and Road Initiative. Area Dev. Policy 2016, 1, 323-340. [CrossRef]

15. International Air Transport Association (IATA). World Air Transport Statistics 2017 Mediaki Edition; International Air Transport Association: Montreal, QC, Canada, 2017.

16. Zhang, A.; Chen, H. Evolution of China 's air transport development and policy towards internation. Transp. J. 2003, 42, 31-49.

17. Jin, F.J.; Wang, F.H.; Liu, Y. Geographic Patterns of Air Passenger Transport in China 1980 - 1998: Imprints of Economic Growth, Regional Inequality, and Network Development. Prof. Geogr. 2004, 56, 471-487.

18. Zhang, Y.; Round, D.K. China's airline deregulation since 1997 and the driving forces behind the 2002 airline consolidations. J. Air Transp. Manag. 2008, 14, 130-142. [CrossRef]

19. Du, W.-B.; Zhou, X.-L.; Lordan, O.; Wang, Z.; Zhao, C.; Zhu, Y.-B. Analysis of the Chinese Airline Network as multi-layer networks. Transp. Res. Part E Logist. Transp. Rev. 2016, 89, 108-116. [CrossRef]

20. Wang, J.; Mo, H.; Wang, F. Evolution of air transport network of China 1930-2012. J. Transp. Geogr. 2014, 40, 145-158. [CrossRef]

21. Lei, Z.; O'Connell, J.F. The evolving landscape of Chinese aviation policies and impact of a deregulating environment on Chinese carriers. J. Transp. Geogr. 2011, 19, 829-839. [CrossRef]

22. Chang, Y.-C.; Hsu, C.-J.; Lin, J.-R. A historic move - the opening of direct flights between Taiwan and China. J. Transp. Geogr. 2011, 19, 255-264. [CrossRef]

23. Ma, X.; Timberlake, M.F. Identifying China's leading world city: a network approach. GeoJournal 2008, 71, 19-35. [CrossRef]

24. Jiang, C. The history of China's aviation; Tsinghua University: Beijing, 2000.

25. Wang, C.; Jin, F. Spatial evolement of China inernational relation through analyzing aviation international networks. Econ. Geogr. 2005, 25, 667-672. 
26. Zhang, Q.; Yang, H.; Wang, Q. Market conduct of the three busiest airline routes in China. J. Transp. Econ. Policy 2013, 47, 335-347.

27. Zhao, S.X.B.; Zhang, L. Foreign Direct Investment and the Formation of Global City-Regions in China. Reg. Stud. 2007, 41, 979-994. [CrossRef]

28. Van De Vijver, E.; Derudder, B.; Witlox, F. Exploring causality in trade and air passenger travel relationships: the case of Asia-Pacific, 1980-2010. J. Transp. Geogr. 2014, 34, 142-150. [CrossRef]

29. Yang, H.; Dobruszkes, F.; Wang, J.; Dijst, M.; Witte, P. Comparing China's urban systems in high-speed railway and airline networks. J. Transp. Geogr. 2018, 68, 233-244. [CrossRef]

30. Neal, Z. The devil is in the details: Differences in air traffic networks by scale, species, and season. Soc. Networks 2014, 38, 63-73. [CrossRef]

31. Lei, Z.; Yu, M.; Chen, R.; O'Connell, J.F. Liberalization of China-US air transport market: Assessing the impacts of the 2004 and 2007 protocols. J. Transp. Geogr. 2016, 50, 24-32. [CrossRef]

32. Zhang, Y.; Zheng, X.; Lu, W. Measuring the openness of Chinese international air transport policy. Transp. Policy 2018, 1-10. [CrossRef]

33. Zhao, X. International Air Transportation Liberalization and China'sAir Transport Industry. Air Transp. 2007, $75,58-62$.

34. Ren, S.; Yuan, B.; Ma, X.; Chen, X. International trade, FDI (foreign direct investment) and embodied CO2 emissions: A case study of chinas industrial sectors. China Econ. Rev. 2014, 28, 123-134. [CrossRef]

35. Graham, A. Managing Airports, Third Edition: An international perspective, 3rd ed.; Routledge: London, UK, 2009.

36. Liu, G.; Hu, J. Study on measurement of relationship between China 's foreign trade and air transport growth. Air Transp. 2015, 33, 36-40.

(C) 2019 by the authors. Licensee MDPI, Basel, Switzerland. This article is an open access article distributed under the terms and conditions of the Creative Commons Attribution (CC BY) license (http://creativecommons.org/licenses/by/4.0/). 